\title{
Contributions to a semiotics of religion: the semiosis from sign to meaning
}

\author{
Paulo Barroso \\ Instituto Politécnico de Viseu - pbarroso1062@gmail.com
}

\begin{abstract}
This article approaches theoretically the religious experience in toto. Considering the semiotics applied to religion, contributions to understand and recognize the relevance of this discipline are proposed. Such approach to the semiotics of religion justifies the aim of the article: to understand the meaning structures of religious experiences. These experiences are diverse, intimate, subjective, but all have an idea of the "transcendent" as a referent and they are based on structures of meaning, expressions, and representations of the sacred, forms, uses and interpretations of religious signs, systems of collective thought and symbolic action. It is

intended to advocate that: 1) the semiotics of religion is an interdisciplinary branch of social sciences and humanities and a sort of semiotics of culture; religion is a form of culture, as well communication and social meaning; 2) religion is a semiotic phenomenon; it is sustained by signs, representations, processes of signification and cultural construction of the world, without which there could be no religion. This is followed by a conceptual, theoretical strategy of critical discussion of the structures of meaning on which manifest culture is based through what we say or do, the way we behave and the attitude we have towards signs.
\end{abstract}

Keywords: culture, religious experience, semiosis, semiotics of religion, sign.

\section{Contribuições para a semiótica da religião: a semiose do signo ao significado}

\section{Resumo}

Este artigo aborda teoricamente a experiência religiosa in toto. Considerando a semiótica aplicada à religião, propõem-se contribuições para compreender e reconhecer a relevância desta disciplina. Tal abordagem da semiótica da religião justifica o objectivo do artigo: compreender as estruturas de significado das experiências religiosas. Essas experiências são diversas, íntimas, subjectivas, mas todas têm uma ideia do "transcendente" como referente e são baseadas em estruturas de significado, expressões e representações do sagrado, formas, usos e interpretações de signos religiosos, sistemas de pensamento colectivo e acção simbólica. Pretende-se sustentar que: 1) a semiótica da religião é um ramo interdisci-

(C) The Author(s) 2021. Open access article published online by Interações: Sociedade e as Novas Modernidades, ISSN: 2184-3929, at https://interacoes-ismt.com, under the terms of the Creative Commons Attribution-NonCommercial 4.0 International Licence (https://creativecommons.org/ 
plinar das ciências sociais e humanas e uma espécie de semiótica da cultura; a religião é uma forma de cultura, assim como comunicação e o significado social; 2) a religião é um fenómeno semiótico; é sustentada por signos, representações, processos de significação e construção cultural do mundo, sem os quais não poderia haver religião. É seguida uma estratégia conceptual e teórica de discussão crítica das estruturas de significado em que se baseia a cultura manifesta, por meio do que dizemos ou fazemos, da maneira como nos comportamos e da atitude que temos em relação aos signos.

Palavras-chave: cultura, experiência religiosa, semiose, semiótica da religião, signo.

\section{INTRODUCTION}

This article follows a conceptual and theoretical strategy. This strategy is that of critical discussion. The object of criticism is the structure of meaning regarding religious experiences. Culture in general and its various forms of expression are based on some structure of meaning. Through what we say or do, the way we behave and the attitude we have in the different religious experiences and in the face of the heterogeneity of religious phenomena, culture manifests itself.

All forms of culture have these dispositions, although they are all different. This article intends to conceptualize and problematize the role of representation of signs, respecting, in the first place, the classical tradition of semiotics, namely the medieval semiotic tradition of Saint Augustine (1991, p. 48), according to which a sign is something that shows itself to the senses and something else to the spirit ("signum est et quod seipsum sensui, et praeter se aliquid animo ostendit"). In this definition of sign presented in De dialectica, Saint Augustine highlights the classical assumption of semiotics: aliquid stat pro aliquo, i.e. something (aliquid) stands for (stat pro) something else (aliquo). What is this "something"? It is the sign, everything which can be taken as significantly substituting or representing for something else. Everything can be a sign. In religious experiences, this recognition is frequent, as the spirit of faith and belief makes certain objects or natural phenomena perceptible and sensitive as signs of the sacred. Therefore, something (any natural object like stones, metals, trees, flowers, animals, fountains, rivers, hills, fire, air, etc. or something abstract like a geometric shape, number, idea, etc.) is a sign only because it is interpreted as a sign 
of something (e.g. the sacred) by someone (the interpreter). A sign is always something that means (and stands for, substitute, represent) something to someone.

The classical and fundamental substrate of semiotics is this expression aliquid stat pro aliquo, stressing that we become aware of signs through the senses, experiences, and that the sign always tells us something, it reveals its content to our spirit. Regarding the role of signs and their corresponding meanings, Saint Augustine did not adopt a semiotic concern, but a religious one since his objective was the hermeneutics or exegesis of the meaning of sacred texts. However, Saint Augustine was a forerunner in the approach of a semiotics of religion, as he recognized the requirement and the importance of extracting the meanings of the signs from the significance of the sacred scriptures, on the one hand, and he established an interdisciplinarity between semiotics and hermeneutics, on the other hand.

The meanings of signs have effects. The unveiling of these effects is called a semantic transition, a process from sign to meaning that leads to an imperative of interpretation. The quintessential example of a semantic transition is the process of transubstantiation of Christ's body and blood into bread and wine, respectively (Peirce, 1978, $\S 5.401)$.

If there is a sign, there is a meaning; if there is meaning, there is interpretation, i.e. interpretation is called to capture or extract the meaning. The signs are inserted in complex structures of meaning, which are eminently cultural, they are forms of expression of culture. Meaning structures work based on any presentation and perception of a sign that is always rather than anything else. That is why Saint Augustine affirms that a sign is something that shows itself to the senses and something else to the spirit.

Semiotics studies all cultural phenomena, i.e. all uses, functions and manifestations of culture, because these cultural phenomena are also phenomena of meaning and communication based on system of signs, i.e. on systems composed of signs that, therefore, produce meanings. Therefore, semiotics also studies religion from the perspective in which religious or sacred signs produce and transmit meanings.

Does meaning exist outside the sign? If a sign is what shows, evokes, makes something represented and absent come to sense and spirit, is there a separation between the signifier (formal and sensitive) and the meaning (mental, intelligible) of the sign? Does Saint Augustine propose a non-identity of the sign with itself? In the field of religion and regarding the symbol understood as a subclass of the sign, is there an essence of language and communication (interaction) with the sacred? 
According to Todorov (1979, p. 33), this definition of sign by Saint Augustine is on a semantic level and it fulfils the designation function, referring to the interpreter's mind as a third correlate of semiosis. This reveals an original property of the sign, that of the non-identity of the sign with itself. The sign is double, i.e. sensitive and intelligible. What characterizes a sign is the representative or designative mediation it makes of a third party.

But in Confessions, Saint Augustine $(2014, \S 8)$ states that, after hearing the signs, thought turns to the things signified. This passage on the acquisition and use of language is a simplistic pictorial conception, which intends to reveal the essence of human language. For Wittgenstein $(1996, \S 1)$, this essence does not exist because language is used in a relative way and the Augustinian conception is restricted to words that name objects, to the conviction that all words have their respective meanings.

With the title "Contributions to a semiotics of religion: semiosis and the passage from sign to meaning" semiotics is categorically assumed as the area that best fits this approach, despite the vast scope of its field of study. Effectively, the study of signs in any field, such as religion, starts from the axiom that the sign is a fundamental unit or element of communication processes and systems of meaning.

If we have signs, we have a code where they are located and articulate, because all communication involves signs and codes. Signs are artefacts or acts that refer to something other than themselves, that is, they are significant constructions. As we highlighted, this is the classic assumption of semiotics. One thing (sensible, present, and antecedent) is instead (representing) something else (intelligible, absent, and consequential). We become aware of signs through the sensitive experience. We can only account or perceive something in the outside world through the mediation of the sign, as it always tells us something, reveals its content to our spirit.

In turn, "codes are the systems into which signs are organized and which determine how signs may be related to each other" (Fiske, 2002, p. 1). The process of meaning is only verified when there is a code, as Umberto Eco $(2007$, p. 6) assures. Whenever something materially present to the recipient's perception is for something else, the meaning is verified (Eco, 2007, p. 6). A system of meaning is based on rules and a code; it is a semiotic construct.

Therefore, this article presents itself as a proposal to approach semiotics on religious experience. Religious experience is understood with the characteristics identified by Gurvitch (1961, p. 130): a) it consists of a form of mystical experience distinct 
from other forms of experience of the immediate; $b$ ) it is necessarily a collective experience; c) it overlaps with all other experiences, founding and uniting them.

This proposal for a semiotic approach on religious experience underlies the imperative of communication. Communication is based on the regularity of a system of conventions. Furthermore, communication is innate in human beings, it is a property of human nature and various forms of culture. Communication is a human process and a social phenomenon. This proposal fits and is justified within the semiotics of religion itself, a field of study which is interested in studying and understanding the structures of meaning of religious experience, expressions, and representations of the sacred, forms, uses and interpretations of symbolism, collective thought systems and symbolic action. All these topics of study serve to demonstrate that the common use of forms and systems of meaning follow or build social, ethical, moral, and religious values sustained in social and cultural forms of life, processes of social interaction and in the conditions of externalization, rationality, and regulation. They do this when they are related to religious experience.

\section{WHAT IS THE SEMIOTICS OF RELIGION?}

The semiotics of religion is, above all, semiotics applied to religion. It is the study, understanding and interpretation of religious signs (among which the symbols, more properly used in the field of religion) in cults and rites that define religious experiences. The semiotics of religion is a semiotics of culture. Religion is culture, as is communication and meaning. It is important and interesting to study and understand the signs used in religious practices. However, these signs are not understood as equivalences or fixed correspondences between signifier and signified. Signs are understood to imply more complex cultural relations than the correspondence between signifier and signified.

The semiotics of religion is the focus on the study of communication and significance systems of sign structures that support the various religious experiences, cults, rites, beliefs, and practices on transcendental entities. The semiotics of religion is the study of system of signs and their uses and references within structures of meaning. It includes cultural elements that define a religion, its beliefs, practices, expressions and production of meanings, perceptions of semiosis processes or semiotic ideologies (Yelle, 2013, p. 3). These elements have implications for the way life is formed and 
for the ways of seeing, thinking, feeling, acting, and representing reality. Religion is a semiotic phenomenon, because it is based on signs, representations, and processes of meaning in the world and processes of social construction of the world. Without signs there could be no religion, culture, or social relations.

Religious rites are of interest to the semiotics of religion from the moment they are practices of meaning and communication and include the representation and transmission of meanings, as well as integrating systems and structures of signs that support religious experiences and practices. In rituals, signs must show through their use that they follow their logic and composition. Thus, signs unfold their own dynamics and effectiveness, which can be attributed to them based on characteristics such as sequence, regularity, referentiality or formality (Kreinath, 2006, p. 429).

Rituals are composed of signs and form a system or structure of meaning. Rituals are religious or mystical ceremonies and reconcile forms and contents of collective life through the production of meanings. They are timeless and ubiquitous ceremonies in social life, as they are part of the symbolic universe of organization and cultural expression of communities. Without signs, rituals would not be constituted as a set of consecrated practices based on observed and followed traditions, customs, values, or norms. Meanings, virtues, and symbolic powers within rituals are attributed to the ways of acting, behaviors and gestures to produce certain effects or results. At least, results of understanding what signs mean and actions and reactions triggered according to what one interprets and understands about signs. The semiotics of ritual is justified through the recognition of the symbolic role of the ceremony and its signs and meanings. In the field of religion, rituals are part of a set of life experiences based on religious phenomena.

The semiotic perspective of ritual establishes an understanding of symbols, whose social functions are the practice, meaning and preservation of rituals understood as formal and social ceremonies. If all cultures and all their manifestations are understood within a system of signs, in this system not only the signs are important, but also the interactions and combinations of signs.

Thus, structuralism conceives the formation of a language of culture from these systems, considering that each of its elements (symbols, norms, values, beliefs) contributes to this system and turns it into a semiotic system and makes it fulfil its social functions. The constituent elements of any system only mean if they are inserted in the system to which they belong and being in relation to the other elements. The semiotics of religion focuses on the territories of syntax (study of the relationship 
between signs and the rules that follow and organize them), semantics (study of the relationship of signs with their referents) and pragmatics (study of the relationship of signs with their interpretants and with the sensible effects that the signs provoke on them) of any system or structure of signification.

Rituals are forms of expression and manifestation, social practices in which signs are processed and signify or produce meanings and effects. Rituals are one of the focuses of semiotics, as are all aspects that allow understanding all forms of production, transmission (expression) and reception (perception and recognition) of meanings and senses. In the field of religion, these forms are sometimes unconscious, and most are ancestral, traditional and rooted in social and cultural practices. That is why Saussure's structuralism is based on the perspective of semiotics as a science which studies the life of signs within the social life (Saussure, 1916, p. 33).

\section{SEMIOTICS AS THE STUDY OF CULTURE SYSTEMS}

There are no signs without codes, nor are there signs and codes without culture. In this premise, semiotics (as a study of signs) is involved in the study of culture in which signs and codes participate, i.e. these are cultural systems. Signs and codes are culturally transmitted, become accessible to all participants in a culture and on which they intervene by communicating, receiving and transmitting signs in codified messages and, therefore, repeating practices that feed social relations. Communication is multiform and essential for collective life and for the maintenance and integration of a culture. If there is no communication without culture or culture without communication, the study of communication is also the study of culture that integrates communication as a practice and social interaction through the mediation of signs.

The inherent association between communication and culture is identical to the also inherent association between communication and religion, as religion is a cultural modality, i.e. a way of living a culture. The semiotics of religion is interested in studying and understanding the role of signs in the definition of religious practices that are inherently cultural and social practices of collective interaction. For example, defining and understanding the meanings associated with religious beliefs and practices; the pragmatics and regulation of the social use of signs (religious symbols) and their sensitive and spiritual effects on believers, depending on the meanings and 
senses produced and received; the representation, symbolism and performativity of the language inherent in the act and ritual of communication; the issue of representation based on the collective and cultural construction of forms of communication and meaning, as well as ways of thinking, feeling and acting symbolically on the sacred, which are sine qua non conditions to integrate, participate and interact in a culture.

Therefore, it is underlined the importance of signs and symbols (the last understood as a subclass of signs) in the forms of expression and in the processes of communication and systems of meaning involving religious experiences. The aim is to critically understand and interpret the systems of meaning and communication processes of everyday religious experiences, that is, the modes of production and consumption of signs that characterize these social and cultural practices.

Considering that the study, investigation and understanding of all systems of meaning and processes of communication and social representation using signs and systems of codes in which they are inserted is characteristic of semiotics, the semiotics of religion is an area of study that it encompasses in its field of investigation the systems and processes that occur in cultures and societies with religious experiences. All these systems and processes are eminently human and develop, transmit and maintain themselves in social contexts and situations. Following the approach of semiotics of religion, the understanding is focused on the ways in which the production, transmission, and reception of meanings in phenomena, manifestations and religious experiences operates, contributing to the critical and comprehensive analysis of the forms of social, cultural, and symbolic construction of reality.

According to Peter Berger and Thomas Luckmann (1991, p. 33), "everyday life presents itself as a reality interpreted by men and subjectively meaningful to them as a coherent world". This is what makes or allows religion as a semiotic construction on everyday life and a reality interpreted and endowed with meanings.

Therefore, a semiotic and hermeneutic approach to religious experience is justified. Such approach is based on signs and their respective meanings, resulting in symbolism and identity for the community of sign interpreters that uses and shares the system and structure of meaning. In this approach, communication and culture are the same, considering that, as Umberto Eco (2001, p. xvii) points out, all cultural phenomena are facts or communication phenomena regulated by codes.

Religious phenomena and experiences are based on systems of meaning and communication processes. If any semiotic phenomenon is a cultural and social phenomenon, it rests on systems of rules and codes, as well as on processes of produc- 
tion, transfer, and consumption of meanings. Therefore, semiotics has to do with what can be assumed to be a sign, i.e. something (a stimulus, the signifier) substitute or representative for something else (a response, the signified).

There is an inevitable and indisputable link between semiotics and the study of culture. The realm of signs or the semiosphere (Lotman, 2005, p. 208) and consequent meanings includes all cultural manifestations and forms of meaning production, as in the cases of religious experiences and phenomena. This realm or semiosphere is the sphere of signs, the space or system of semiotics, without which communication and meaning cannot take place (Hartley, 2004, p. 207).

Semiotics studies all cultural phenomena as if they were sign systems. All cultural phenomena are systems of signs, i.e. communication phenomena, as recognized by Umberto Eco (2001, p. 3) in The absent structure. Culture is communication and can be explained according to coding schemes that preside over communication processes. In this perspective, Umberto Eco (2001, p. 3) considers culture as all human intervention on what nature give us, modified so that it can be inserted in a social relationship. Culture is only experienced if it is converted into signs and inserted into an understandable system.

Considering that the religious experience is a form of cultural manifestation and, therefore, it is based on a system of signs that express beliefs and values through cults and symbolic rites, the religious experience falls within the field of semiotic studies, respecting Saussure's structuralist perspective, according to which semiology is a science that studies the life of signs within social life.

Therefore, religion is of interest as a privileged field of communication and meaning/symbolization in this approach. A field where ritualized and collective systems of meaning and communication processes operate. As religion is a cultural variant, a varied range of ways of life and social practice according to the dictates of each religion, the field of communication studies is underlying, as "communication constitutes the core of culture and indeed of life itself", according to Edward Hall (1966, p. 1) in The hidden dimension, and religion is a way of living, feeling and expressing culture.

Effectively, communication and religion are social phenomena. Communication is the product of biological and social factors: biological because it is innate and all living organisms emit and receive signals of expression or exteriorization and of identification or recognition; social because human relationships are fundamental to religion and are based on the meaning, symbolization and representation of attitudes, 
feelings, behaviors, symbolic thoughts, ways of life and ritualized actions. Human relationships have meanings and are part of cultural patterns, because they work on the basis of models of reality and means of communication, that is, messages are transmitted and meanings are represented based on concepts elaborated by the human senses.

The production and use of objects and signs with their respective meanings is culture and it transforms the human being's relationship with nature and with other human beings. These relationships are multiple and multiform, on the one hand, and reveal how culture is a phenomenon of meaning and communication. Culture is manifested in daily practices, customs, and habits, social behavior and, therefore, also in religious experiences, which are eminently symbolic. As such, culture and religion must be studied as semiotic phenomena. As Umberto Eco (2007, p. 16) underlines, all aspects of culture can be studied as contents of a semiotic activity. For Umberto Eco, culture is just communication, and it is based on a system of structured meanings.

This thesis supports the communicational perspective on religious experience. According to Umberto Eco (2007, p. 16), this proposal should be reformulated as follows: culture (as a whole) should be studied as a communication phenomenon based on systems of meaning. Umberto Eco (2007, p. 21) emphasises that contemplating culture in its globality sub specie semiotic does not mean that the whole culture is just communication and meaning, but that culture (in its complexity) can be better understood if it is approached from a semiotic point of view. The objects, behaviors and values of a culture "work" as they are and serve because they obey semiotic laws.

Meanings are cultural conventions. Culture is a significant practice in which everything that is done or said falls within the framework of a system made up of elements that are also components of religion: 1) symbols (which carry meanings between people); 2) language (symbol system to signify and/or communicate); 3) values (which socially structure interpersonal relationships as desirable cultural standards); 4) beliefs (a creed held as revealing the truth in which one believes); 5) norms (agreed and admissible social practices).

As a significant practice, culture manifests itself in different forms, practices, customs and social behaviors that produce meanings. Therefore, culture within all these elements fulfil the function of meaning. Culture presupposes symbolic and characteristic forms that are identified, recognized, and followed. Culture is always manifested through symbolism, language, and forms of representation. 
For example, the word "God", which is a sign, and all other signs (tangible and intangible) that represent or evoke God cause ambiguity and misunderstandings as to its referent, which is transcendental, but always signify a supreme and fundamental reality: the sacred. From the perspective of the semiotics of religion, it is not possible to believe in God without certain concepts (Otero, 2003, p. 86). Concepts are ideas, representations with meanings sustained using signs, and they serve to speak more effectively of immanent reality than of the transcendent reality of God.

The word "God" is common among the most diverse cultures and antagonistic perspectives of conceiving and understanding the world. It's a common word, but with a fundamental meaning. However, as George Steiner points out, the referent of the word "God" is enigmatic or unknown. Hence, this word is a grammatical ghost, says Steiner (2013, p. 7) in Real presences. Despite this, the use of the word as a sign normalizes and guides the thoughts, speeches, attitudes, behaviors, and actions of people, especially believers of various religions. The word is a multi-significant sign that helps to understand religious experiences and their meanings and social functions. For Steiner, it is relevant what he calls "images from the past" to understand what governs us, that is, what culture is, as In bluebeard's castle: Some notes towards the re-definition of culture demonstrates: "It is not the literal past that rules us, save, possibly, in a biological sense. It is images of the past. These are often as highly structured and selective as myths." (Steiner, 1971, p. 3). Steiner underlines the images and symbolic constructs of the past that are imprinted on our sensibility.

\subsection{What is a symbol?}

The symbol is a sub-class of sign. Like all signs, it is an element of mediation and signification. The symbol is an artifact and, as such, it constitutes the object of the semiosis process, i.e. of the dynamic process of perception and recognition of a representational relationship between the symbol and its meaning.

The etymology of the word "symbol" (from the Greek symbolon, "sign of recognition") is a sine qua non condition for any representation. Culture is a symbolic system of adaptation to the environment and of transforming the natural and biological condition of the Human into a cultural and symbolic condition. The reality is both physical and symbolic. The human being is an animal symbolicum, says Cassirer (1954, p. 33) in An Essay on Man: An Introduction to a Philosophy of Human Culture. 
If the human being is a animal symbolicum, how important is the symbolic function for everyday experiences in general and religious experiences? According to Cassirer (1972, p. 49-58), a symbol is a sign that represents an idea, an emotion, a desire, a social form. It is a conventional signal, collectively agreed upon in a culture. It is assumed that the community assimilate and share the meanings and references that symbol stipulate.

But symbols indirectly refer to a physical reality and show themselves directly to a figuration, a "mental reality", i.e. a thought or imagined reality of meanings and senses. A symbol is a unity of meaning of a conventional nature, which is interpreted as representing something that is not the unity itself, because it is in place or instead of something as a result of a habit. Symbols are arbitrary and have no intrinsic meanings. Symbols become symbols only when they are recognized and used with reference to a given code. A code is a system, as is the case of religion, where symbols fulfil fundamental functions for believers who recognize transcendental representations in them and thus receive the practical effects resulting from the immediate and sensitive interpretation of symbols.

As a rule, the symbol of "something" does not designate the objective and essential totality of the thing symbolized. The symbol of "something" only designates what it can mean or can be made to mean in a ghostly frame of reference or context, according to George Devereux (1979, p. 19). Devereux emphasizes that a psychological component is associated with the symbol, determining what any symbol means or what it refers to as the bearer of a certain, specific, and socially conventionalized and contextualized meaning.

In turn, Guy Rocher (1998, p. 82) defines the symbol as anything that takes the place of something else or anything that replaces and evokes something else. This definition is classic and shows that the symbol implies a signifier (what takes the place, the symbol itself), a meaning (the thing that the signifier replaces) and the signification (the relation between the signifier and the signified, which must be apprehended and interpreted). It is this symbolic aptitude and ability to apprehend and understand the relationships between the signifier and the meaning that characterizes Cassirer's symbolicum animal and distinguishes it from other animal species. The aptitude to use symbols of the symbolicum animal requires certain physiological developments (in the brain, skull, face and upper limbs), both for the elaboration and understanding of symbols and for the manufacture of survival instruments. Thus, an essential anthropological dimension is presupposed in symbols, without which 
different cultures could not represent and manifest phenomena intrinsic to their different ways of living and being in the world, as in the case of what is considered to constitute the "sacred".

A symbol is what represents a thing, it is in place of something, and this may be symbolized differently according to each culture. According to Gurvitch's Sociology of law, symbols simultaneously reveal and conceal, or rather they reveal by concealing and conceal by revealing. "The symbols are the inadequate sensitive expressions of spiritual meanings, taking the place between appearances and things in themselves" (Gurvitch, 2001, p. 35). Symbols are intermediaries; "they simultaneously reveal and conceal, or rather they reveal by concealing and conceal by revealing. What they express and what they hide is on the one hand the spiritual, on the other reality (physical, biological, psychological, sociological), in which the spirit partly embodies itself, partly reveals itself" (Gurvitch, 2001, p. 35).

In this symbolic perspective on culture, it is also understood that culture is communication and communication is culture. It is not possible to have communication without the transmission of signs. Culture is all human intervention on the Natural (i.e. what is given without human intervention), modifying it so that it can be integrated into a social relationship. Culture is an ordered system of meanings, symbols, beliefs, and values that allow social interaction and integration.

Symbols always mean more than what they convey; they appeal to the imagination, they give food to think. According to The Conflict of Interpretations: Essays in Hermeneutics, Ricoeur (2004, p. 28), argues that "the symbol invites us to think, calls for an interpretation, precisely because it says more than it says and because it never ceases to speak to us". It is the symbol that gives us the meaning it already has. This possession of meaning in symbols is an exclusive condition for a symbol to be a symbol.

For example, let us consider the relationship between symbol and myth, where this "something else to think about" that Ricoeur refers to is explored and evident. Within a "show-hide" game, myth is unfathomable, mystical, transcendental, and allegorical in its multiple meanings. Myth is a collective mental construction about reality. The myth is a stolen and restored speech, according to Roland Barthes (1991, p. 124), in which the restored speech is no longer entirely the same as it had been subtracted (when using it, it was not replaced exactly in their place). It is this stealing (a sort of furtive moment of a counterfeit) that constitutes the transfixed aspect of mythical speech. 
Any natural object (e.g. stones, metals, trees, flowers, animals, fountains, rivers, hills, fire, air, etc.) or abstract (e.g. geometrical shape, number, idea, etc.) can acquire a symbolic value. For believers in a symbolic-religious ritual, everything that involves a given religious ceremony and the worship is sacred and meaningful. Space, time, Nature, iconographic representations of religious figures, etc., are never understood in themselves, i.e. in a simple and exclusively natural condition as they are in reality, but they are always perceived with a certain religious symbolism and value. Human beings have an intimate and social need to sacralise the world in which they live. It is the strength of belief that drives collective life, interpersonal relationships, social behaviors, actions and attitudes towards aspects of earthly existence.

"The world stands displayed in such a manner that, in contemplating it, religious man discovers the many modalities of the sacred, and hence of being", points out Eliade (1987, p. 116). It is in this condition that the human being unveils the different modalities of hierophany and ontophany in which, for example, a stone is venerated when it is considered sacred (Eliade, 1987, p. 11). A simple stone reveals symbolism, it becomes sacred because it is believed to manifest or represent a sacred force or a divine entity (Eliade, 1972, p. 390).

Let us recall the mentioned example of the transubstantiation of Christ's body and blood into bread and wine (Peirce, 1978, \$5.401). The bread and wine lose their physical dimensions and become symbols interpreted as the body and blood of Christ. In this transubstantiation process, the symbol's power and function of representation is evidenced, as they serve to stimulate ideas associated with the signs in thought and are used as means of representing these ideas (Bolzano, 1972, p. 308).

Like all signs, symbols are stimuli and trigger responses. In Symbolism: Its meaning and effect, Whitehead (1927, p. 16) emphasises that the purpose of symbolism is to emphasize the importance of what is symbolized, i.e. the influence of symbolism on human life. In short, symbols participate in building a web of meanings that we call culture (Foster, 1994, p. 367). Symbols are part of the game of representations of a culture. There cannot be any form of culture without symbolism.

\subsection{The semiosis of the symbol: the crucifix}

The crucifix is the image of Christ on the cross, i.e. Christ crucified. The crucifix is a sign, it represents this episode in the life of Christ, but the shape of the crucifix varies. 
Sometimes we see it in one form and sometimes in another form. The way of seeing and interpreting it allows us to question what it means to see the figure in one way at a given moment and in another way at another time. To see a figure in two forms and at two different times is it to see different things or to see the same thing interpreted differently? This questioning focuses sometimes on the form (the subject's way of seeing) and sometimes on the content (the visible nature of the object) of the visual experience. These peculiarities are relevant, for example, of the ways of seeing and of what is seen, of the daily relationship between the field of experience of a codified world and the field of exteriorization of the contents of experience about that world.

The symbol of the cross is diffused in Christianity as meaning the suffering of Christ at the time of the crucifixion. This symbol has multiple forms despite its reference and versions. The cross is present in the religious, mystical, or esoteric dimension, as well as in the history of different peoples such as the Egyptians, Celts, Persians, Romans, Phoenicians, or Indians. In this case, the variations or differences between the Greek cross, the cross of Saint Peter, the cross Tao or the Latin cross are evident. These four forms of crosses are four different symbols in both form and meaning. As they are different crosses and symbols, with different shapes and meanings, the interpretations are also necessarily different, despite referring to the idea of the crucifixion. Thus, the possibility of the subjectivity of experience in seeing and interpreting each symbol differently is admitted. To perceive the symbol of the cross or crucifix as they are usually presented is to recognize a relationship of representation and meaning, but to perceive the symbol of the cross or crucifix in a particular and unusual situation, is to recognize another relationship of representation and meaning. This is the difference between the meaning of the symbol and the sense of the symbol. The meaning of the symbol is just and precisely the representation that it proposes to awaken and normally awakens. The sense of the symbol is the representation that we aim at in a particular case (one can use the symbol in an opposite sense to its real meaning, that is, present or use the inverted cross).

Despite the differences, these two cases of representation and signification, the meaning of the symbol and the sense of the symbol, are both cases of semiosis. Symbol semiosis is the process of recognition of meaning triggered by voluntary and intentional action, based on cultural patterns that are manifested (symbols), with the objective of creating, transmitting, recognizing and interpreting representations.

Semiosis is a phenomenon of perception and meaning. It is a phenomenon because something happens and is empirically perceived through a symbol. It is the 
recognition that a symbol represents a designatum (what the sign refers to, the type of object to which the sign refers, that is, objects possessing the properties that the interpreter knows through the presence of the vehicle of the sign), producing or eliciting an interpretant (a certain effect or response in the interpreter). A sign (or symbol) must have a designatum, but not all signs (or symbols) refer to real, existing objects, so there can be no designata without semiosis (Morris, 1971, p. 34). Semiosis is a process. The signs trigger dynamic relationships of meaning between themselves and what they represent or signify. Semiosis is the apprehension of a sign: the perception and recognition of the presence of a sign as if it wants to tell us something. In a process of semiosis, according to Charles Morris $(1971,34)$, anything starts to play the function of a sign.

The crucifix is the symbol of a revealing moment; it has an important religious meaning; it reproduces and represents a narrative based on a set of priceless collective values and it dispenses any literal representation, as this would result in an incomplete meaning (Ward, 2007, p. 232). In the semiotics of religion, the crucifix is the connoted representation of a cultural message: the idea of Christ on the cross, which means that Christ was a victim of human injustice and malevolence. The same degree of religious (i.e. cultural) significance is present in the antagonistic figure of the Devil, symbol of the evil power that supposedly devastates believers and that confronts the good, represented and connoted by sacred entities (e.g. God, Christ, Virgin Mary or the saints). As a symbol of goodness, God inspires believers to actions (e.g. to pray) that sustain its meaning.

If a believer claims that he has always understood the crucifix symbol in a way, as if he was responding to an echo of thought or memory, he must have acted in accordance with the process of semiosis he has always developed, as he perceives and recognizes the representation or meaning in the symbol that perceives. He makes the semiosis of the symbol as it was inculcated in his culture and stimulated by the symbol. Thus, he must rely on subjectivity and on the differences in the conception of signs, even if they serve the same meaning functions. Believers (including those who profess the same religion) may have a different conception about a certain concept, or they may even wrongly form a concept, determining their thinking about the reality to which that concept corresponds.

Symbolization is part of a cultural process. Symbolization is a conceptual construction of reality. In the different cultural communities, people adapt so that symbolic relationships develop in a more effective and understandable way. Thus, it is under- 
stood that the codification and symbolization of the religious experience presuppose the dualisms inside/outside, impression/expression and language/action. Systems of signs, meaning structures and conceptual maps are formed to designate, describe, or externalize impressions and interpretations, whether subjective or objective.

\section{CONCLUSIONS}

This article approaches the religious experience from the perspective of semiotics, i.e. the religious experience as the designation of the totality of experiences and phenomena based on the sacred and the transcendent, on the one hand, and on the interiority and subjectivity of the subject of the experience, on the other hand. Religious experience is paradoxically collective (in view of the sacred and its symbols) and individual, subjective, heterogeneous, and immanent (despite referring to the transcendent). Religious experience individualizes, as any experience consists of a flow of unique experiences (Rodrigues, 2011, p. 65). It is a subjective way of seeing, being and existing based on religion or what religion allows to experience. A condition for religious experience is the recognition of a primordial meaning: the existence of a sacred entity or supernatural force that is understood as the ultimate origin of all that exists and that manifests itself through signs that reveal messages.

This is where the semiotics of religion fits. The semiotic perspective on religious experience privileges semiotics as a perspective on this experience within the framework of a system of meaning, assuming that the religious experience is symbolic. The religious experience is symbolic because it recognizes the revealing power of symbols. Insofar as it is based on what is lived, religious experience requires the mediation of symbols.

Whoever lives a religious experience acquires a worldview and a relationship with the world that is specific and different, as if everything started to possess and reveal its hidden meaning until then. Therefore, religious experience is the most important among all finite and transitory human experiences. It is the experience that brings the believer and the sacred closer together, provides feelings of protection on the part of the power that is recognized in the sacred, creates identity. Thus, the religious experience directly influences the way of being and existing in the world.

The semiotics of religion focuses on a specific approach on the structures of meaning, systems of sign or symbol, communication processes and forms of language 
in religion. The field of study of semiotics is wide. It encompasses everything that means, that is, all forms of culture, including signification, communication, and language. The semiotics of religion is semiotics applied to representations, symbolisms and meanings that are perceived and recognized in religious experiences. The semiotics of religion focuses on semiosis processes in the field of religion, focusing on phenomena and experiences that manifest and represent ways of living religion. Religion cannot be the object of study of an undiscipline. On the contrary, religion is studied and understood at an interdisciplinary intersection within the social and human sciences. Only in this way an experience as subjective as religious experience or a phenomenon as abstract as religious phenomenon can be understood.

For that reason, the semiotics of religion is the study and interpretation of signs in religious practices and experiences. Signs cannot be understood as fixed correspondences between the signifier and the signified. In this article, it is argued that the semiotics of religion is a semiotics of culture. Religion (also communication, meaning and symbolism) belongs to the domain of culture. Through the study of communication systems and symbol structures that support religious experiences, cults, rites, beliefs, and social practices related to transcendental entities, semiotics is applied to religion and its system of sign and respective uses and meanings within structures of meaning. To do this, it is assumed the cultural elements that define a religion: beliefs, practices, expressions and production of meanings and semiosis processes with implications for the meaning of life and ways of seeing, thinking, feeling, acting and represent reality.

Religion is a semiotic phenomenon. Religion is presented and manifested through the mediation of signs; it is supported by a system and structure of signs, representations and processes of signification and cultural construction of the world, without which there could be no religion or worldview that each form of religious life proposes.

\section{REFERENCES}

Barthes, R. (1991). Mythologies. New York: The Noonday Press.

Berger, P., \& Luckmann, T. (1991). The social construction of reality. London: Penguin Books. 
Bolzano, B. (1972). Theory of science. Berkeley: University of California Press.

Cassirer, E. (1954). An essay on man: An introduction to a philosophy of human culture. New York: Doubleday Anchor Books.

Cassirer, E. (1972). La philosophie des formes symboliques. Paris: Les Éditions de Minuit.

Devereux, G. (1979). Fantasy and symbol as dimensions of reality, in R. H. Hook (ed.) Fantasy and symbol: Studies in anthropological interpretation (pp. 19-31). London: Academic Press Inc.

Eco, U. (2001). A estrutura ausente [The absent structure]. São Paulo: Editora Perspectiva.

Eco, U. (2007). Tratado geral de semiótica [General treatise on semiotics]. São Paulo: Editora Perspectiva.

Eliade, M. (1972). Tratado de historia de las religiones [Treatise on the history of religions]. México: Ediciones Era.

Eliade, M. (1987). The sacred and the profane. New York: A Harvest Book.

Fiske, J. (2002). Introduction to communication studies. London: Routledge.

Foster, M. (1994). Symbolism: the foundation of culture. In T. Ingold, Companion encyclopedia of anthropology: Humanity, culture and social live (pp. 366-395). London: Routledge.

Gurvitch, G. (1961). Morale théorique et sciences des moeurs. Paris: Presses Universitaires de France.

Gurvitch, G. (2001). Sociology of law. New Jersey: Transaction Publishers.

Hall, E. (1966). The hidden dimension. New York: Doubleday.

Hartley, J. (2004). Communication, cultural and media studies: The key concepts. London: Routledge.

Kreinath, J. (2006). Semiotics, in J. Kreinath, J. Snoek \& M. Stausberg (eds.), Theorizing rituals: Issues, topics, approaches, concepts. (vol. 114-1). Leiden: Brill.

Lotman, Y.(2005). On the semiosphere. Sign System Studies (33-1), 205-226.

Morris, C. (1971). Writings on the general theory of signs. The Hague: Gruyter Mouton. 
Contributions to a semiotics of religion: the semiosis from sign to meaning

Otero, J. C. (2003). Estética y culto iconográfico. Madrid: Biblioteca de Autores Cristianos.

Peirce, C. (1978). Collected papers. (5 vols.) Cambridge, Massachusetts: Harvard University Press.

Ricoeur, P. (2004). The conflict of interpretations: Essays in hermeneutics. London: Continuum.

Rocher, G. (1998). Sociologia geral: A ação social [General sociology: Social action]. Lisboa: Editorial Presença.

Rodrigues, A. D. (2011). O paradigma comunicacional: História e teorias [The communication paradigm: History and theories]. Lisboa: Fundação Calouste Gulbenkian.

Saint Augustine (1991). De dialectica. Bucuresti: Humanitas.

Saint Augustine (2014). Confissões [Confessions]. São Paulo: Paulus Editora.

Saussure, F. (1916). Cours de linguistique générale. Paris: Editions Payot.

Steiner, G. (1971). In bluebeard's castle: Some notes towards the re-definition of culture. Yale: Yale University Press.

Steiner, G. (2013). Real presences. New York: Open Road Integrated Media.

Todorov, T. (1979). Teorias do símbolo [Symbol theories]. Lisboa: Edições 70.

Ward, K. (2007). Deus e os filósofos [God and the philosophers]. Cruz Quebrada: Estrela Polar.

Whitehead, A. (1927). Symbolism: Its meaning and effect. Virginia: University of Virginia.

Wittgenstein, L. (1996). Philosophical investigations. Oxford: Blackwell.

Yelle, R. A. (2013). Semiotics of religion: Signs of the sacred in history. London: Bloomsbury. 